Hydraulic Engineering Repository

Ein Service der Bundesanstalt für Wasserbau

Kösters, Frank; Winter, Christian

Exploring German Bight coastal morphodynamics based on modelled bed shear stress

Originalveröffentlichung / Original Publication:

https://doi.org/10.1007/s00367-013-0346-y

Verfügbar unter / Available at:

https://hdl.handle.net/20.500.11970/104571

Vorgeschlagene Zitierweise / Suggested citation:

Kösters, Frank; Winter, Christian (2013): Exploring German Bight coastal morphodynamics based on modelled bed shear stress. In: Geo-Marine Letters 34. S. 21-36. 
Erstveröffentlichung in Geo-Mar (2014), S. 21-36.

Für eine korrekte Zitierbarkeit ist die Seitennummerierung

der Originalveröffentlichung für jede Seite kenntlich gemacht.

\title{
Exploring German Bight coastal morphodynamics based on modelled bed shear stress
}

\author{
Frank Köstersa, Christian Winterb \\ a Hydraulic Engineering in Coastal Areas, Federal Waterways Engineering and Research Institute, \\ Wedeler Landstrasse 157, 22559 Hamburg, Germany, e-mail: Frank.Koesters@baw.de \\ b MARUM - Center for Marine Environmental Sciences, University of Bremen, Leobener Strasse, \\ 28359 Bremen, Germany
}

Received: 1 July 2013 /Accepted: 29 October 2013 /Published online: 15 November 2013

The prediction of large-scale coastal and estuarine morphodynamics requires a sound understanding of the relevant driving processes and forcing factors. Data- and processbased methods and models suffer from limitations when applied individually to investigate these systems and, therefore, a combined approach is needed. The morphodynamics of coastal environments can be assessed in terms of a mean bed elevation range (BER), which is the difference of the lowest to highest seabed elevation occurring within a defined timeinterval. In this study of the coastal sector of the German Bight, North Sea, the highly variable distribution of observed BER for the period 1984-2006 is correlated to local bed shear stresses based on hindcast simulations with a wellvalidated high-resolution (typically 1,000m in coastal settings) processbased numerical model of the North Sea. A significant correlation of the 95th percentile of bed shear stress and BER was found, explaining between $49 \%$ and $60 \%$ of the observed variance of the BER under realistic forcing conditions. The model then was applied to differentiate the effects of three main hydrodynamic drivers, i.e. tides, wind-induced currents, and waves. Large-scale mapping of these model results quantify previous qualitative suggestions: tides act as main drivers of the East Frisian coast, whereas waves are more relevant for the morphodynamics of the German west coast. Tidal currents are the main driver of the very high morphological activity of the tidal channels of the Ems, Weser and Elbe estuaries, the Jade Bay, and tidal inlets between the islands. This also holds for the backbarrier tidal flats of the North FrisianWadden Sea. The morphodynamics of the foreshore areas of the barrier island systems are mainly wave-driven; in the deeper areas tides, waves and wind-driven currents have a combined effect. The open tidal flats (outer Ems, Neuwerker Watt, Dithmarschen Bight) are affected by a combination of tides, wind-driven currents and waves. Model performance should be measurably improved by integrating the roles of other key drivers, notably sediment dynamics and salt marsh stabilisation. 


\section{Introduction}

Coastal morphodynamics involve the interaction of bed topography and sediments with hydrodynamics and sediment transport processes driven by forcing factors such as tides, winds and other physical forcing mechanisms. The continu ous mutual adjustment of forcing hydrodynamics and the sediment bed, dynamic and static boundary conditions has led to a vastly variable coastal geomorphology (for recent overviews, see Flemming and Hansom 2011; Masselink et al. 2011). The prediction of coastal morphological evolution is complex because the relevant processes range across multiple spatial scales, from micro-scale feedback mechanisms at the sediment grain-size level (e.g. Cowell and Thom 1994) over the dynamic formation of deltas (Edmonds and Slingerland 2007) to the evolution of coastlines (Roelvink and Reniers 2012). Time periods associated with these morphological elements range from seconds to geological timescales. Spatial and temporal scales are commonly seen as coupled entities-e.g. micro-scale processes are described in very short time intervals, and the evolution of coastlines due to sea-level rise or isostatic subsidence in geological timescales (Vink et al. 2007). Intermediate scales describe effects such as the impact of single storms on coastal features like sand bars

Kösters, Winter: Exploring German Bight coastal morphodynamics based on modelled bed shear stress.

Geo-Mar Lett 34 (2014), S. 21-36.

or the effect of daily to annual tidal forcing on the migration of tidal channels or tidal inlets.

In order to predict morphological changes and better understand the forcing mechanisms involved, morphodynamic models of different complexities have been applied (see overview by Syvitski et al. 2010). Almost a decade after the work of Lesser et al. (2004), who presented one of the first threedimensional (3D) morphodynamic models, processbased 3D modelling of coastal morphodynamics is still a challenge. Lesser et al. (2004) pointed out the difficulty to combine short hydrodynamic and long morphodynamic timescales in a coupled model, as well as the parameter sensitivity of sediment transport modelling. Despite these complexities, progress has been made in long-term coastal morphodynamic modelling at various locations worldwide, especially in regional studies dealing with tidal bays such as San Pablo Bay, California (van der Wegen et al. 2011) and Suisun Bay, California (Ganju et al. 2011), tidal flats in, for example, the south-eastern German Bight (Junge et al. 2006), and estuaries such as the Schelde in The Netherlands (Dam et al. 2008), the Elbe (Chu et al. 2013) and the Eider in Germany (Winter 2006), and the Vilaine in France (Vested et al. 2013). When expanding the spatial scale in the order of $>100 \mathrm{~km}$, the challenge to apply and validate 3D process-based models for long-term applications in a realistic environment has still to be met.

As far as coastal engineering applications are concerned, morphological changes with timescales in the order of months to tens of years are of significant socioeconomic relevance for, among others, the safety of navigational channels, coastal constructions, or sub-seafloor pipelines and cables and 
coastal zone management (e.g. Brommer and Bochev-van der Burgh 2009). These dimensions are commonly referred to as "engineering spatiotemporal scales". In the light of human impact to coastal environments and the ongoing large-scale climate change, an indepth understanding of coastal morphodynamics is crucial. This naturallyholds globally and for all (populated) coastal environments.

This study addresses coastal morphodynamics at engineering spatiotemporal scales for the German Bight, North Sea (Fig. 1), which serves as example for a very diverse and dynamic coastal environment. The German Bight coastline is a mixed wave- and meso- to macrotidal environment featuring barrier islands, tidal inlets, estuaries, and the open as well as the backbarrier tidal flats of the Wadden Sea (Winter and Bartholomä 2006). The German Bightwaters are important gateways to major German ports and a navigational approach to and from the Baltic Sea. The region is subject to various socioeconomic interests such as offshore wind farms, fishing, and environmental conservation. The morphological evolution of the German Bight has been shown to react to different combinations of tidal or wind-driven currents and waves based on morphological data on migrating tidal channels, dynamic tidal flats and ebb-tidal deltas, and foreshore areas (e.g. Zeiler et al. 2000;Winter 2011; Son et al. 2011). As no feasible technique enables the direct and continuous observation of large-scale three-dimensional hydrodynamics, sediment transportand seabed morphology, the key drivers which produced the observed morphological states necessarily cannot be measured directly.

Estimates of long-term (order of centuries) residual sediment transport patterns have been based on the interpretation of sedimentological and stratigraphic data which show the net depositional character of the German Bight (Zeiler et al. 2008). On shorter timescales, morphologically active regions of the German Bight have been identified based on the analysis of remote sensing data (Niedermeier et al. 2005) or bathymetric data (Winter 2011). These have shown that the highest morphological activity can be found in the outer estuary tidal channels of the East Frisian coast and along the German west coast. Considering the known distribution of tidal currents and wave energy along the German Bight coastline, it was hypothesized that the main morphodynamic drivers along the East Frisian coast are the tidal currents, whereas the high morphologic activity along the North Frisian coast can also be related to wave forcing. This study aims at a more sophisticated quantification in relating the observed morphological evolution to relevant drivers by means of processbased numerical model simulations.

Coupled hydrodynamic-sediment transport models support a detailed investigation of individual processes and can provide synoptic morphological and hydrodynamic states. There exists a range of sediment transport model studies for the North Sea covering the German Bight. In an early study, residual suspended sediment transport rates were calculated by Puls et al. (1997) who obtained a sediment budgetfor the German Bight, and found a net sedimentation in the order of $1.3 \mathrm{Mt} / \mathrm{year}$ for the years 1990-1991. The overall structure of sediment transport has been investigated for the whole North Sea (e.g. Gerritsen et al. 2001) and the German Bight (e.g. Stanev et al. 2009) by comparing model results and remote sensing data. These identified the large-scale structure of nearsurface suspended sediment transport from satellite images. The influences of tides, wind and waves on sediment transport patterns in the North Sea were previously assessed in a twodimensional 
(2D) process-based modelling study which emphasized the dominance of wind-driven flow and waves in the German Bight (van der Molen 2002). In that study, regional features such as tidal channels could not be resolved due to a rather coarse model resolution (7-9 km). On a smaller scale detailed studies of sediment transport characteristics have been conducted in, for example, the East Frisian area by means of numerical modelling (Staneva et al. 2009) and observations (Flöser et al. 2011). That work contributed to an improved understanding of relevant suspended sediment

Kösters, Winter: Exploring German Bight coastal morphodynamics based on modelled bed shear stress.

Geo-Mar Lett 34 (2014), S. 21-36.

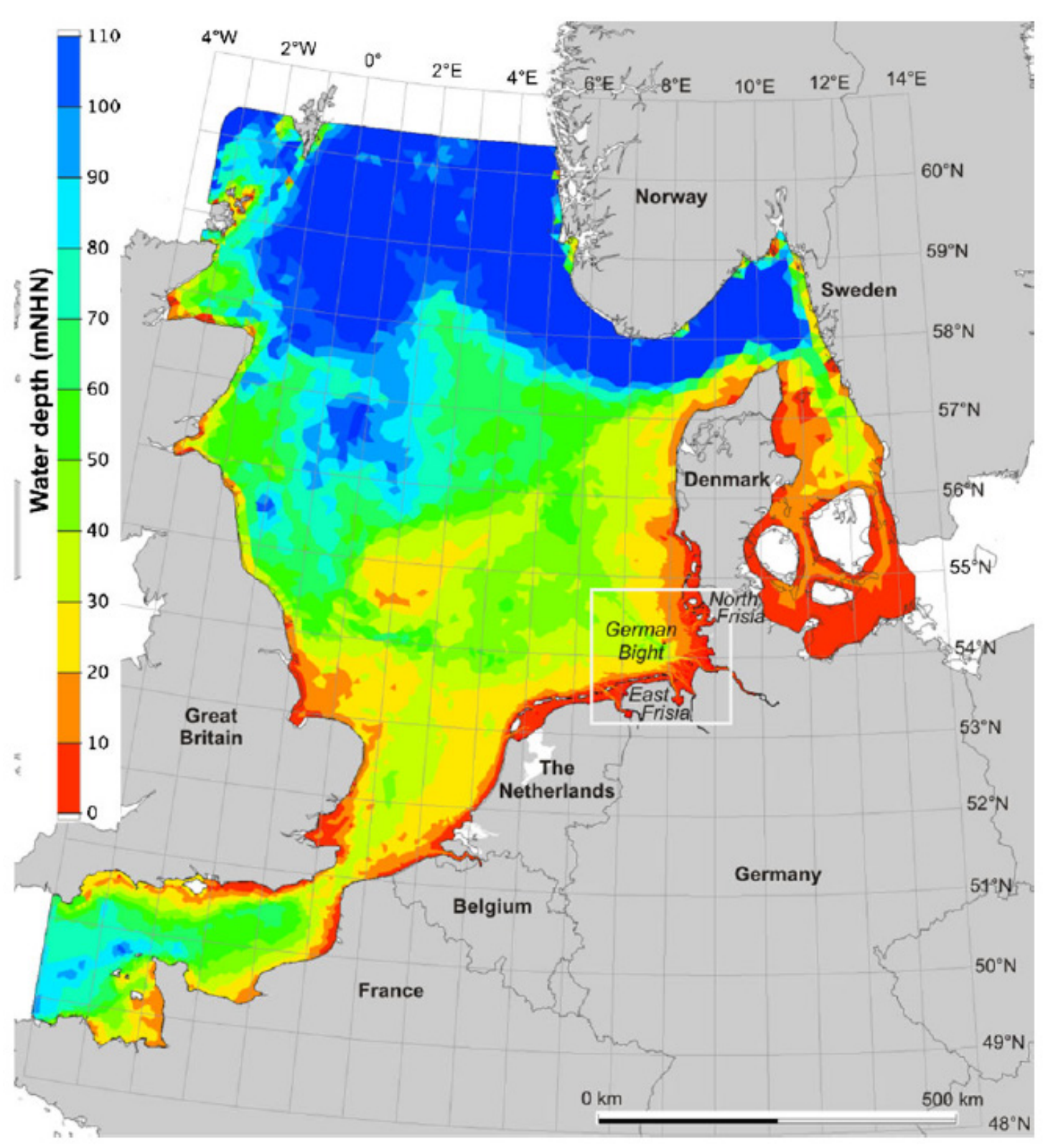


Fig. 1 Topography of the North Sea as represented by the unstructured model grid. The study area of the German Bight is depicted by the rectangle. Water depths are given relative to the German chart datum of mNHN (Normalhöhennull, in m)

transport processes but did not considermorphological changes. On the other hand, the abovementioned morphodynamic modelling studies have not discussed the effect of different forcing factors.

This article attempts to bridge this gap by investigating hydrological and meteorological conditions as the driving forces for morphological changes. As a measure of hydrodynamic drivers, the spatial distribution of bed shear stress is analysed. This has previously been shown to be a suitable measure of suspended sediment dynamics in the southern North Sea (Stanev et al. 2009). A wellvalidated 3D hydrodynamic model of the North Sea is applied to derive local bed shear stress differences depending on different forcing conditions, which are then assessed in conjunction with the observed morphological activity. Based on these analyses the relevant forcing factors of morphodynamics in the coastal sector of the German Bight are identified.

\section{Physical setting}

The German Bight has a relatively shallow shelf at water depths between 20 and $40 \mathrm{~m}$ in offshore waters. The coastline is highly diverse, featuring the Wadden Sea with its Frisian

\section{Kösters, Winter: Exploring German Bight coastal morphodynamics based on modelled bed shear stress. Geo-Mar Lett 34 (2014), S. 21-36.}

barrier islands and tidal inlets along the East Frisian and North Frisian coastal sectors, associated with vast open as well as backbarrier tidal flats. Furthermore, the region comprises Jade Bay and the four estuaries Ems, Weser, Elbe and Eider (Fig. 1). The East Frisian barrier islands consist of old dune cores (Ehlers 1988) which have formed due to landward sediment transport, whereas the North Frisian islands are marshland islands originating from the Pleistocene (Flemming and Davis 1994; Schwarzer et al. 2008).

The regional oceanography of the North Sea has been intensively studied in the past (see reviews by, among others, Otto et al. 1990; Sündermann and Pohlmann 2011) and is monitored on a regular basis by the relevant national authorities (e.g. Loewe et al. 2013). Typical values of the tidal range are in the order of 2-4 $\mathrm{m}$. The prevailing wind direction is west, setting up a cyclonic residual circulation. Different circulation patterns (anti-cyclonic, unidirectional) are less frequently found. The German North Sea coast is exposed to a long fetch over the North Sea; typical values for the 99th 
percentile of significant wave height for the German Bightare in the order of $4 \mathrm{~m}$ (Weisse and Günther 2007).

\section{Materials and methods}

\section{Data-based analysis}

Morphological changes are defined as the temporal change in bed elevation at location $z(t)$. The morphological change $\Delta z=z\left(t_{2}\right)-z\left(t_{1}\right)$ represents the residual of erosion and deposition in the period $t_{1}$ to $t_{2}$. Local changes may have various causes-e.g. large-scale erosional and depositional processes, or the migration of a tidal channel. As a measure of longerterm morphological activity, a bed elevation range (BER) can be defined for a series of digital elevation models (DEMs) as

$$
\operatorname{BER}_{i, j}=\operatorname{MAX}\left(z_{i, j}(t)\right)-\operatorname{MIN}\left(z_{i, j}(t)\right)
$$

in whichMAX $\left(z_{i, j}\right)$ is the maximumelevation of the seabed at a DEM grid node $(i, j)$ throughout time $t$ , and $\operatorname{MIN}\left(z_{i, j}\right)$ is the minimum elevation of the seabed at the same grid node. The resulting BER can be understood as the range of morphological activity throughout the data-collection period. The BER has been previously calculated and mapped to describe the decadal morphodynamic activity of the German Bight based on bathymetric data from the years 1984 to 2006 (Winter 2011) and the Dutch continental shelf (van Dijk et al. 2012).

The German Bight data were recomputed here, filtered for outliers, and furthermore normalised by division with the maximum period covered by available data at each grid node (Fig. 2). This results in a spatial distribution of the average morphodynamic activity in meters per year. The BER is a relative indicator of morphodynamic activity. Absolute numbers may contain errors to some degree. Although a thorough quality control of input data has been performed, several factors may bias the absolute values. These factors contain the technical inaccuracies of field measurements (performed throughout two decades) and their projection and interpolation on the base grids. As most of the data were obtained as gridded datasets from the relevantauthorities, no exact quantification of errors is possible (Winter 2011). It is assumed that inaccuracies may range up to a few decimetres, which is accounted for in the following figures as cut off for a BER $<0.5 \mathrm{~m}$ and the BER colourmap scale. It should be noted that other, certainly important characteristics of coastal morphodynamics are not captured by the BER, such as transport paths, morphological acceleration, etc.

\section{Process-based model}

Bed shear stress is the fluid force per unit area on the bed, and relates to sediment transport andmorphological activity where a mobile bed occurs. In coastal environments, bed shear stress is governed by tidal, wind- and wave-driven currents, and waves. In this study bed shear stresses were calculated with a process-based hydrodynamic numerical model. The 3D hydrodynamic modelling system UnTRIM (Casulli and Zanolli 2005) was used for a model setup of the North Sea (Fig. 1), and coupled to the sediment transport module SediMorph (http://www.baw.de/downloads 


\section{Autorenfassung}

Kösters, Winter: Exploring German Bight coastal morphodynamics based on modelled bed shear stress, 2014

/wasserbau/mathematische_verfahren/pdf/vd-sedimorph.pdf) and an unstructured grid version of the spectral wave k-model (Schneggenburger et al. 2000). The unstructured computational grid (77,500 triangular elements) has a resolution varying from $24,000 \mathrm{~m}$ in the outer North Sea down to $80 \mathrm{~m}$ in the estuaries. The here most relevant typical resolution is $300 \mathrm{~min}$ the tidal channels and $1,000 \mathrm{~m}$ in coastal settings.

In order to represent the natural variability in meteorological forcing, a 12-year period has been simulated (1996-2007). Topographic and sedimentological data were obtained from the AufMod project data base (AufMod is the German acronym for "Model-based analysis of long-term morphodynamic processes in the German Bight"; data available via http://www.mdi-de.org). Each year was computed employing a grid representing the bed topography for that year. The annual bed topographies are based on data down to a water depth of $20 \mathrm{~m}$; areas deeper than $20 \mathrm{~m}$ are the same for the various years, by reason of lacking data. The composition of sediments at the bed is represented as ten different sediment fractions based on the Udden-Wentworth scale ranging from gravel to very fine silt. Sediments with a diameter larger than gravel, e.g. boulders, are included as gravel and sediments finer as fine silt are included as fine silt. Based on the spatially variable sediment distribution, characteristic values such as the mean grain size $\left(d_{M}\right)$ and median

Kösters, Winter: Exploring German Bight coastal morphodynamics based on modelled bed shear stress. 


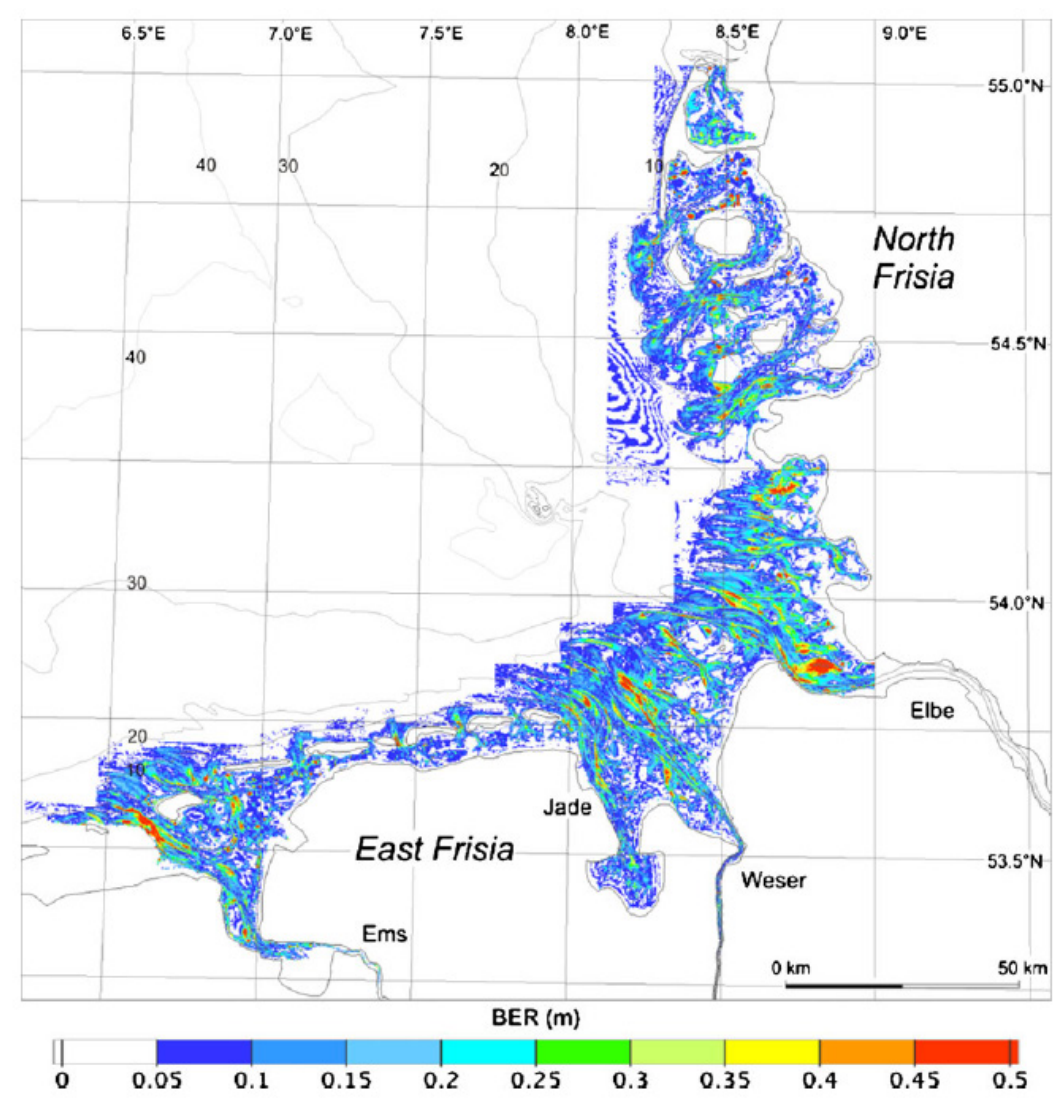

Fig. 2: $\quad$ Average bed elevation range (m/year) based on bathymetric data (1984-2006) as integral measure of morphological changes (recomputed from Winter 2011)

grain size $\left(d_{50}\right)$ are calculated to derive a sediment grainrelated roughness.

The model was forced at the surface boundary with time and space variable wind stress obtained from the operational German National Meteorological Service (DWD) weather forecast models available for the individual years-e.g. COSMO/LM (Doms et al. 2002) and COSMO-EU/LME (http://www.cosmo-model.org/content/model/general/default. htm). At the lateral open sea boundaries, harmonic surface water levels are prescribed. These tidal signals were derived from the global tide model FES2 004 (Lyard et al. 2006), and add to variations in mean sea level obtained from the operational North Atlantic model of the German Federal Maritime and Hydrographic Agency (BSH). River discharge was included as daily values for rivers in the German Bight (data provided by the Federal Waterways and Shipping Administration) and seasonal averages for rivers outside the German Bight based on Gayer et al. (2006). While the model does include salt transport, heat transport is not taken into account. Simulations were performed on a SGI Linux Cluster. A model validation (cf.http://www.baw.de/methoden/index.php5/Validierungsstudien_Nordsee, in German) has been performed concerning the propagation of the tidal wave using over 90 tide gauges. The representation of water levels is close to observed values, yielding a root mean square error of less than $0.4 \mathrm{~m}$ in the German Bight. 
In this study the main model results analysed are bed shearstresses. These are calculated for every time step $(\Delta t=120 \mathrm{~s})$,

\section{Kösters, Winter: Exploring German Bight coastal morphodynamics} based on modelled bed shear stress. Geo-Mar Lett 34 (2014), S. 21-36.

stored every 20 minutes, and can be utilised as a measure of hydrodynamic forcing on the bed. The current-induced component of bed shear stress $\left(\tau_{B, c}\right)$ is related to shear velocity $u^{*}$ as

$$
\tau_{B, c}=\rho \cdot u^{2 *}
$$

with density of water $\rho$ (Soulsby 1997). In a 3D hydrodynamic model the shear velocity can be obtained from the velocity in the lowest layer assuming a logarithmic velocity profile in that layer. Following van Rijn (1993) this can be expressed as

$$
\vec{\tau}_{\mathrm{B}, \mathrm{c}}=\rho \frac{\kappa^{2}}{\left(\ln \frac{0.37 \bullet h^{\prime}}{z_{0}}\right)^{2}}\left|\vec{u}_{\mathrm{B}, \mathrm{c}}\right| \vec{u}_{\mathrm{B}, \mathrm{c}}
$$

in which $\rho$ is the density of water, $\kappa=0.41$ the von Karman constant, $h^{\prime}$ the height of the water column (i.e. the thickness of the lowest layer of the discretised water column),$\vec{u}_{B, c}$ the velocity near the bed and $z_{0}$ the bed roughness length. Following Malcherek (2010), $z_{0}=\frac{k_{\mathrm{s}}^{\mathrm{g}}}{30}=\frac{3}{30} \bullet \bar{d}_{\mathrm{M}} \quad$ where $d_{M}$ is the mean grain size and the grain-related Nikuradse roughness. Here only the grain-related roughness is taken into account, which is assumed to determine sediment transport; the form roughness due to bedforms and ripples is not accounted for. In the derivation of Eq. 3 from van Rijn (1993, equation 2.2.8 for rough flow), usage was made of the fact that, for a logarithmic velocity profile, the mean velocity equals the velocity at 0.37 times the height of the water column $h^{\prime}$.

In order to obtain the combined effect of currents and waves, Malcherek (2010) proposed an iterative solution for $\mathrm{u}^{* \max }$. If waves are present, then the maximum shear velocity $u^{*}{ }^{*}$ ax can be treated as vector sum of the mean current $\vec{\tau}_{B, C}$ and mean wave $\vec{\tau}_{B, w}$ related bed shearstress where $\rho$ is water $\vec{u}_{*}^{\max }\left|\vec{u}_{*}^{\max }\right|=\frac{1}{\rho}\left(\vec{\tau}_{\mathrm{B}, \mathrm{c}}+\vec{\tau}_{\mathrm{B}, \mathrm{W}}\right)$ density (Grant and Madsen 1979). First, the bed shear stress due to currents $\tau_{B, c}$ is calculated following Eq. 3. Second, the bed shear stress due to waves $\vec{\tau}_{B, w}$ is calculated as

$$
\vec{\tau}_{\mathrm{B}, \mathrm{w}}=f_{\mathrm{W}} \rho \frac{A^{2} g k}{\sinh (2 k h)} \cos \left(\omega t \vec{n}_{\mathrm{W}}\right)
$$


with wave friction factor $f_{W}$, density of water $\rho$, wave orbital excursion length $A$, acceleration due to gravity $g=9.81 \mathrm{~m} / \mathrm{s}^{2}$, wave number $k$, water depth $h$, radian frequency of waves $\omega$ based on the wave dispersion relation $\omega=g k \tanh (k h)$, normal vector of the wave $\vec{n}_{w}$ and the time $t . \vec{\tau}_{B, w}$ is only implicitly known since the wave friction factor $f_{W}$, defined as

$$
f_{\mathrm{W}}=\frac{u_{*}^{\max }}{u_{\mathrm{B}, \mathrm{w}}^{\max }} \frac{2 \kappa}{\sqrt{\left(\ln \frac{\kappa u_{*}^{\max }}{\omega z_{0}}\right)^{2}+\left(\frac{\pi}{2}\right)^{2}}}
$$

with $\kappa=0.41$ the von Karman constant, $\omega$ the radian frequency of waves and roughness length $z_{0}$ defined as above (Malcherek 2010), depends on both the maximum shear velocity $u^{*} \max$ and the maximum wave orbital velocity $u^{w B m a x}$. Third, $u^{*} \max$ is determined from

$$
u_{*}^{\max }=\sqrt{\frac{1}{\rho} \sqrt{\left(\tau_{\mathrm{B}, \mathrm{c}}\right)^{2}+\left(\tau_{\mathrm{B}, \mathrm{w}}\right)^{2}+2 \tau_{\mathrm{B}, \mathrm{c}} \tau_{\mathrm{B}, \mathrm{w}} \cos \gamma}}
$$

with density of water $\rho$, mean current $\tau_{B, c}$ and mean wave $\tau_{B, w}$ bed shear stress, and $\gamma$ the angle between current and waves. A starting value for $u^{*} \max$ is the shear velocity of currents alone, and the combined effect of currents and waves is found after a few iterations.

Two diagnostic variables are defined based on the instantaneous bed shear stress values: (1) the 95th percentile of local bed shear stress $\tau_{95}$ depicts a representative value of high bed shear stress; under the assumption of a mobile bed, sediment transport scales with bed shear stress; thus, this value in the following is used as an estimator for sediment transport magnitude; (2) the bed shear stress intensity (BSSI) is defined as the percentage of time when the local bed shear stress exceeds the local critical bed shear stress for erosion (equation SC 77 in Soulsby 1997); thus, this value in the following is used as an estimator for sediment transport duration. The critical bed shear stress for erosion is based on the spatially varying median sediment grain size, $d_{50}$ (see Fig. 3 ). The BSSI can be seen as a measure of the effective energy transfer from the water column to the bed determining the maximum duration of sediment transport, and thus completes the information obtained from $\tau_{95}$. On tidal flats the interpretation of BSSI must consider that bed shear stress here can only be calculated when covered with water. Hence, the BSSI can never reach a value of $100 \%$ in intertidal regions.

\section{Results}

\section{Diagnostic variables of bed shear stress}

Different model simulations of the time period 1996 to 2007 were used for the derivation of bed shear stresses. In order to separate the effect of different forcing mechanisms, i.e. tides, winds and waves, three different model scenarios are further analysed here: (1) forcing only by tides (T), (2) 


\section{Autorenfassung}

Kösters, Winter: Exploring German Bight coastal morphodynamics based on modelled bed shear stress, 2014

forcing by tides and wind stress (TW), and (3) forcing by tides, wind stress and waves (TWS). For each experiment the diagnostic variables $\tau_{95}$ (95th percentile of bed shear stress) and BSSI were determined.For tidal forcing only (experiment $T$ ), the highest bed shear stresses $\tau_{95}$ mainly concentrate on the deeper tidal channels of the main estuaries and tidal inlets between the barrier islands (Fig. 4a). Here typical values

\section{Kösters, Winter: Exploring German Bight coastal morphodynamics based on modelled bed shear stress. Geo-Mar Lett 34 (2014), S. 21-36.}

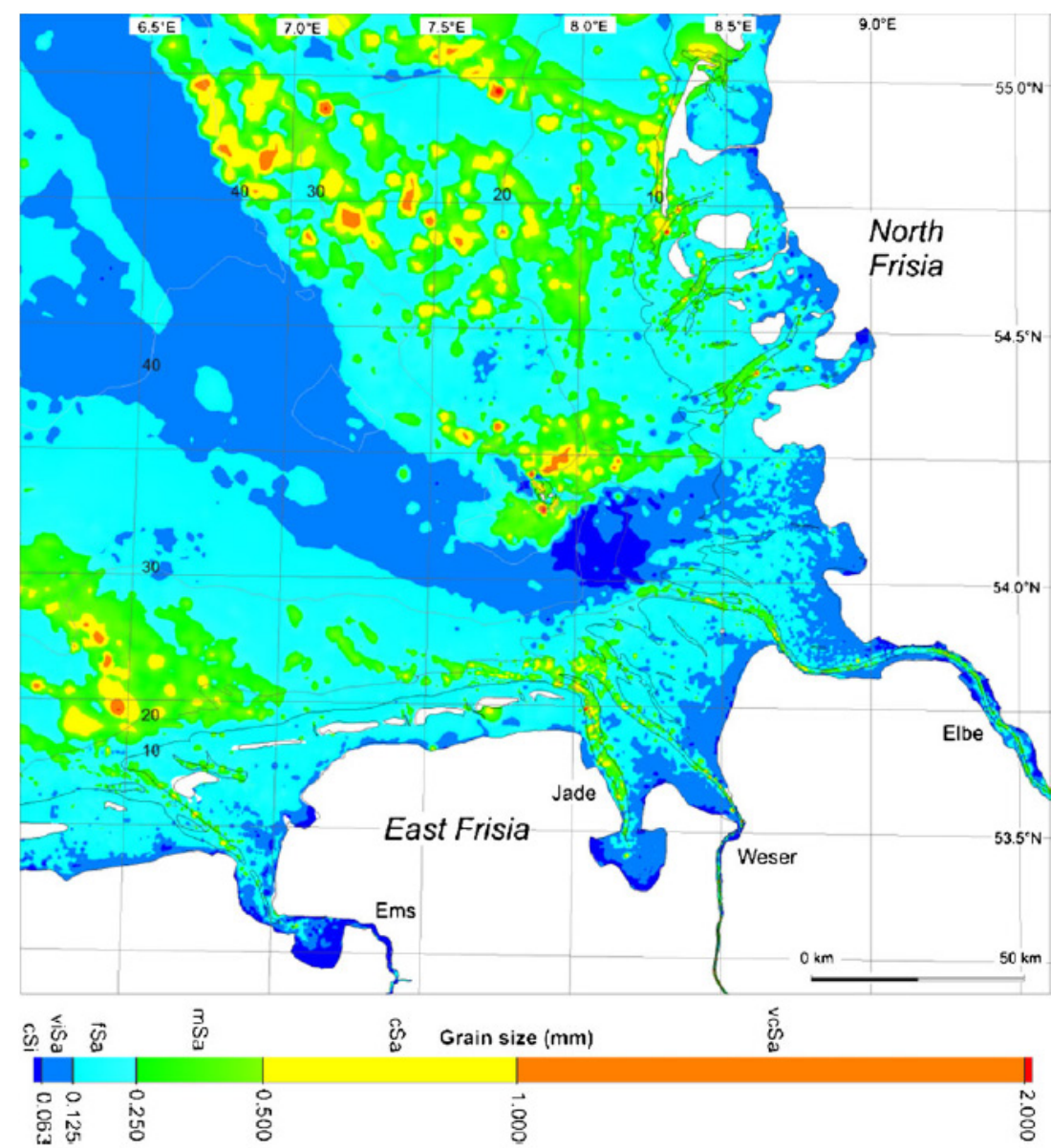

Fig. 3 Observed sediment median grain size distribution $\left(d_{50}\right)$ of the German Bight(AufMod project data base). $v c S a$ Very coarse sand, $c S a$ coarse sand, $m S a$ medium sand, $f S a$ fine sand, vfSa very fine sand and $c S i$ coarse silt, according to the Udden-Wentworth classification

exceed $2 \mathrm{~N} / \mathrm{m}^{2}$ within the main channels and are $>0.9 \mathrm{~N} / \mathrm{m}^{2}$ at their mouths. The additional effect of wind stress on the currents (Fig. 4b) is comparatively small, as can be seen from the difference $T W-$ 


\section{Autorenfassung}

Kösters, Winter: Exploring German Bight coastal morphodynamics based on modelled bed shear stress, 2014

$T$ (Fig. 5a). The additional shear stresses remain below $0.15 \mathrm{~N} / \mathrm{m}^{2}$. Negativevalues in the tidal channels reflect the reduction of shear stress in the deep channels because of the increased flow depth in typical north-westerly wind situations when the German Bight experiences a water level setup. When wave action is taken into account, the areas of high $\tau_{95}$ increase (Fig. 4c). The difference between TWS and TW (Fig. 5b) reveals the main effect of waves as an increase of $\tau_{95}$ mainly in the barrier island foreshore areas, the open tidal flats between the Weser and Elbe estuaries, and along the North Frisian islands. Down to a depth of $10 \mathrm{~m}$, the maximum $\tau_{95}$ increases by over $0.3 \mathrm{~N} / \mathrm{m}^{2}$. The BSSI for the three different scenarios is shown in Fig. 6. The map for solely tidally induced BSSI (Fig. 6a) shows that sediments within the tidal channels are mobile most of the time (>80\%). Note that the BSSI is defined for the local $d_{50}$ (cf. Fig. 3) -it thus takes into account the effects of longterm sorting of sediments which resulted in the observed spatially varying sediment distribution. In addition,

Kösters, Winter: Exploring German Bight coastal morphodynamics based on modelled bed shear stress. Geo-Mar Lett 34 (2014), S. 21-36.

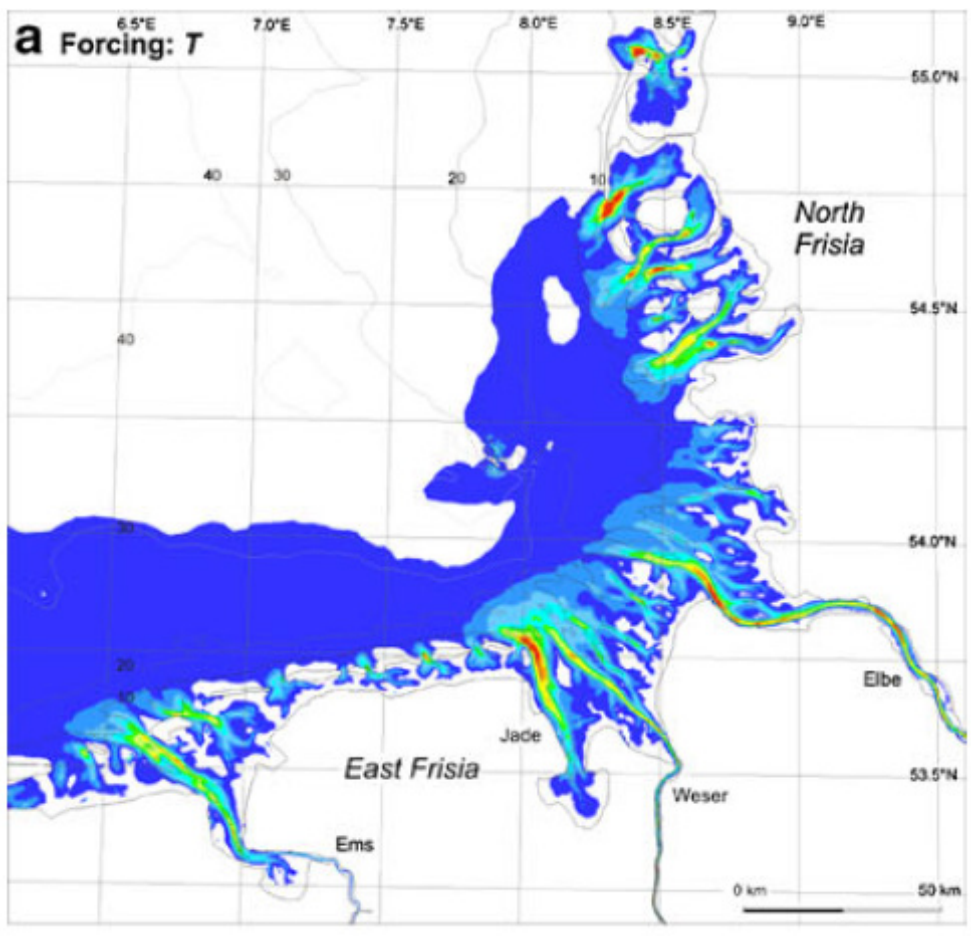



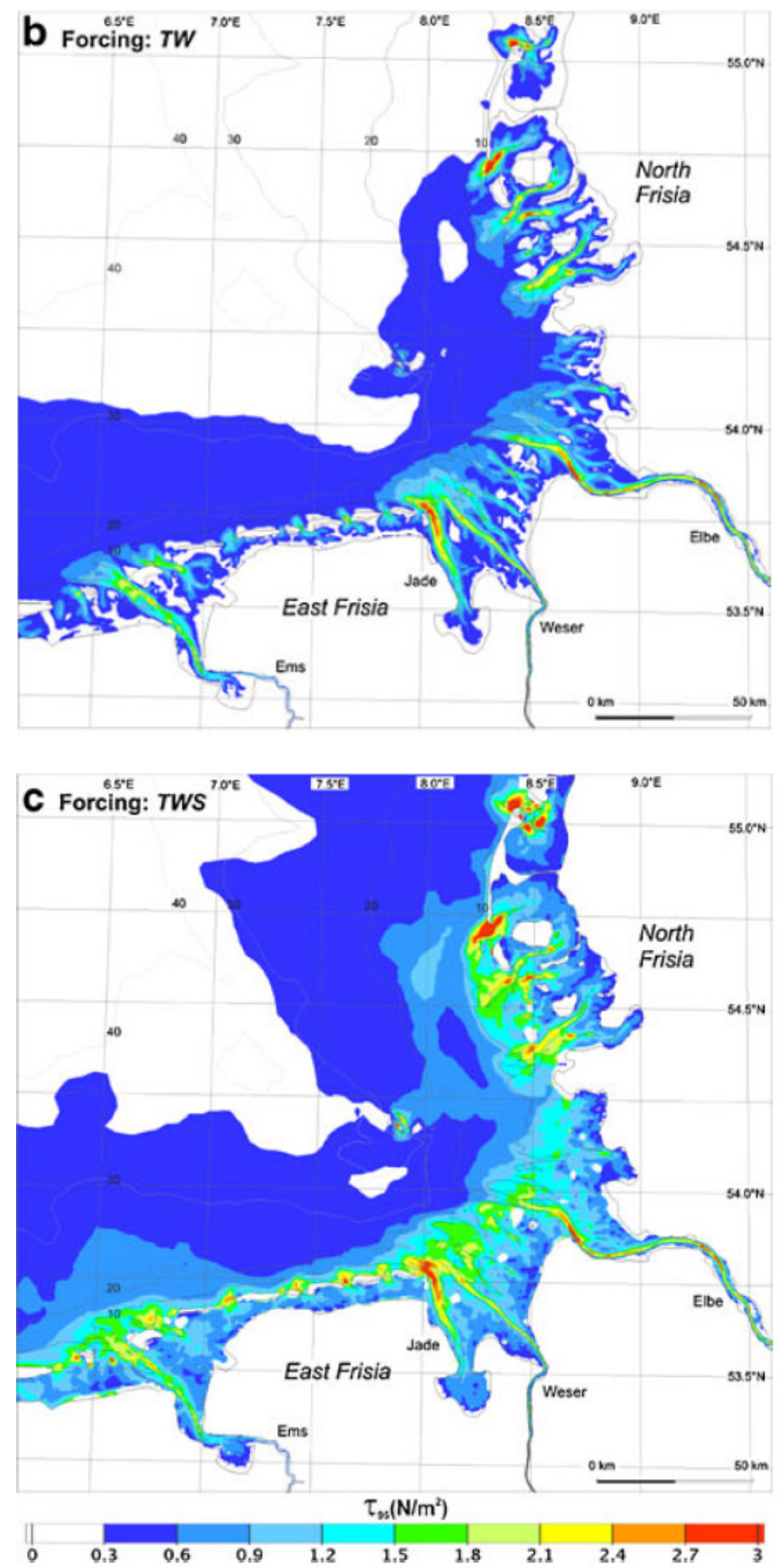

Fig. $4 \quad$ Average $\tau_{95}$ for the time span 1996-2007 for forcing due to a tides only, $\mathbf{b}$ tides and wind stress, and $\mathbf{c}$ tides, wind stress and waves 
large parts of the foreshore area of the East Frisian islands exhibit values over $40 \%$, indicating sediment transport at a depth of more than $20 \mathrm{~m}$. Again, the impact of wind stress (Fig. 6b) is small. The difference $T W-T$ (Fig. 7a) shows local changes in the order of $10 \%$ in the foreshore areas of the East Frisian islands and the North Frisian islands. Significant changes are found when wave action is taken into account (Fig. 6c). Wave action increases the BSSI over almost the whole German Bight by more than $15 \%$. It should be noted that, due to the definition of bed shear stress used here (cf. maximum bed shear stress during a given wave period), the values of BSSI have to be interpreted as an upper limit. The largest increases (Fig. 7b) can be found in the East Frisian foreshore area $(>30$ $\%$ ) and off the northern part of the North Frisian coast. As the East Frisian coast is steeper than the North Frisian coastline, the wave effect is more focused close to the East Frisian islands whereas the dissipation of wave energy extends over a larger area along the North Frisian foreshore. Moreover, the BSSI increases in the tidal flats and sand banks at the mouth of the estuaries.

\section{Correlation of bed evolution range and bed shear stress}

In order to compare results from measurements with model results, the datasets were interpolated to a regular grid with a grid size of $1,250 \mathrm{~m}$. The averaging of measured data was restricted to cells of the coarser grid containing at least eight valid data points to avoid an over-interpretation of poorly sampled grid cells.

The correlations of BER and $\tau_{95}$ as well as BER and BSSI are shown in regression plots for the scenario TWS evaluated for the German Bight (Fig. 8). For a better interpretation of scattered data, additional statistical parameters are shown. The BSSI was subdivided into classes of $2.5 \%$ and, for each class, the 5 th, 50th and 95th percentile of BER in that class was determined. Accordingly, the $\tau 95$ was subdivided into classes of $0.1 \mathrm{~N} / \mathrm{m}^{2}$, and BER percentiles were calculated. The correlation of BER and BSSI (Fig. 8a) shows an exponential increase up to about $80 \%$ and a following reduction of BER with increasing BSSI. The local maximum of the BER and BSSI relation of about $80 \%$ is due to the only partial water coverage of intertidal areas. The increase of BER with increasing BSSI between $0 \%$ and $60 \%$ is approx. $1 \mathrm{~m}$, whereas the increase of BER between $60 \%$ and $80 \%$ is almost $2 \mathrm{~m}$ - thus, a six-fold stronger reaction. The red reference lines in Fig. 8a show that, for a $95 \%$ confidence level, the BER is expected to be lower than $4 \mathrm{~m}$ when the BSSI is less than $62.5 \%$, or lower than $7 \mathrm{~m}$ for a BSSI of less than $80 \%$. The plot of BER versus $\tau_{95}$ (Fig. 8b) shows an increasing scatter with increasing values of BER and $\tau_{95}$, but the 50 th percentile of the BER suggests a quasi-linear relation with $\tau_{95}$. The linear regression of $\tau_{95}$ and BER explains $49 \%$ of the observed variance of the data. A nonlinear regression taking into 
Kösters, Winter: Exploring German Bight coastal morphodynamics based on modelled bed shear stress. Geo-Mar Lett 34 (2014), S. 21-36.
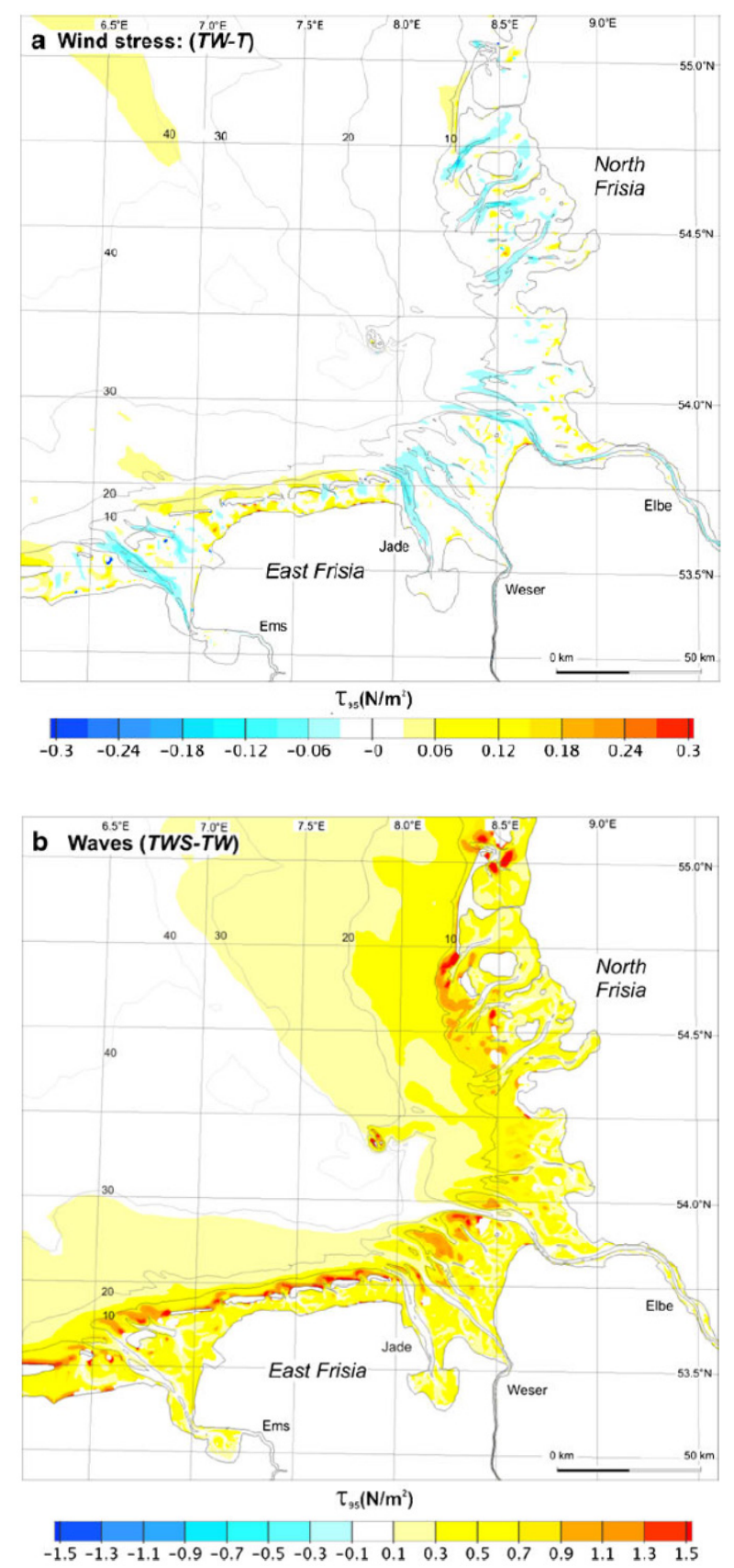

Fig. 5 Difference of $\tau_{95}$ for the impact of a wind stress (TW-T) and $\mathbf{b}$ waves (TWS-TW) 
Kösters, Winter: Exploring German Bight coastal morphodynamics based on modelled bed shear stress. Geo-Mar Lett 34 (2014), S. 21-36.
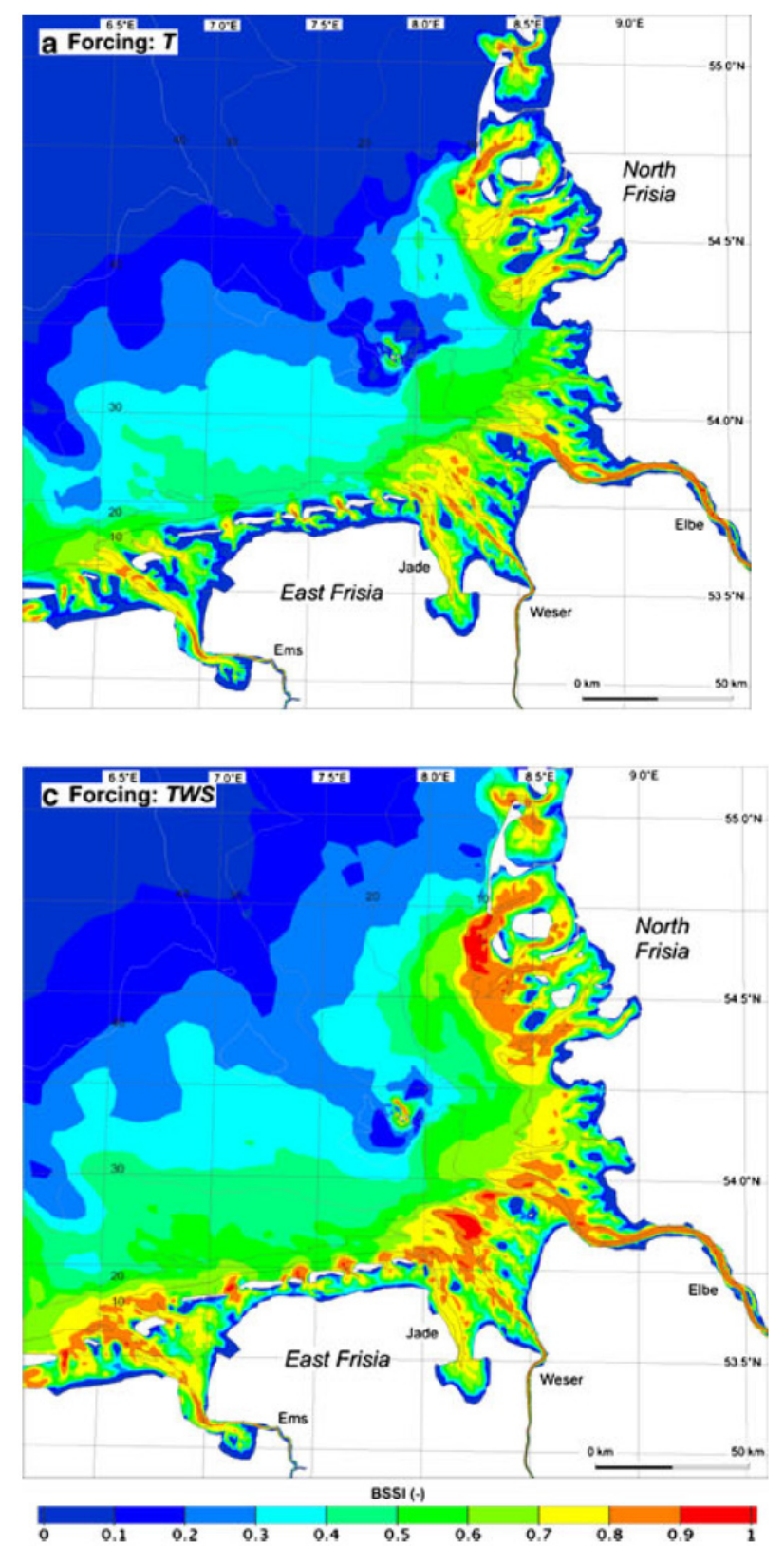


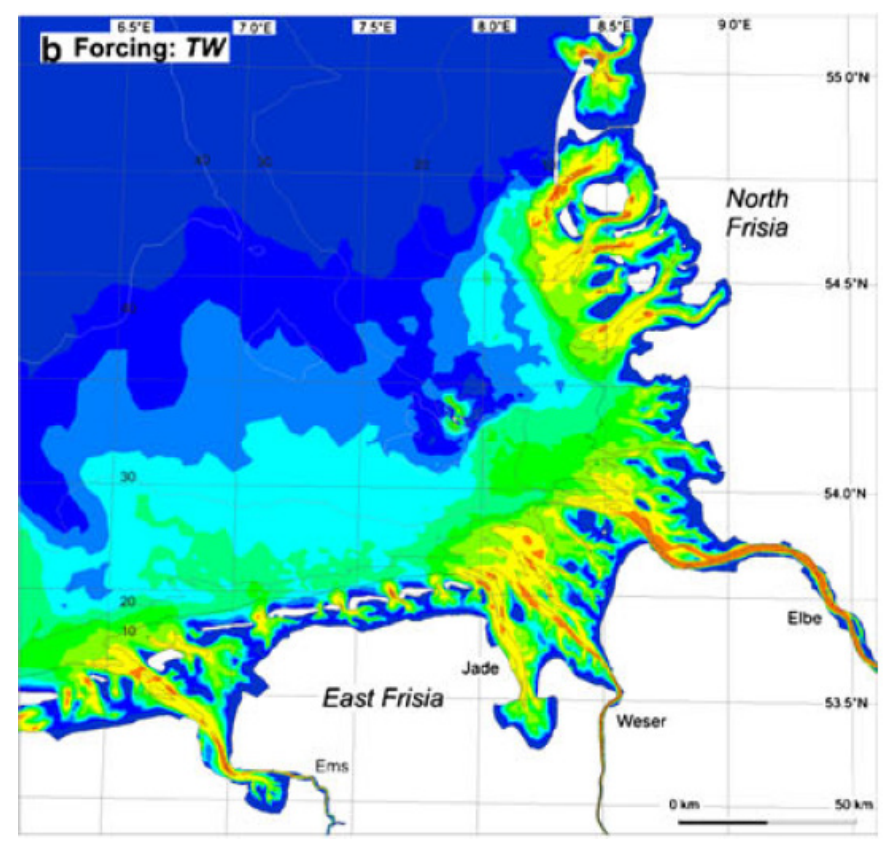

Fig. 6 Average BSSI for the time span 1996-2007 for forcing due to a tides only, b tides and wind stress, and $\mathbf{c}$ tides, wind stress and waves

account that empirical sediment transport formulations are typically a higher power of the bed shear stress than one did not result in an improved correlation. The same regression analysis is performed for the two remaining scenarios $(T, T W)$, which yield higher linear regression coefficients. For setup $T$, the $\mathrm{r}^{2}$ value is 0.59 and for $T W$ it is 0.60 , as compared to $\mathrm{r}^{2}=0.49$ for $T W S$. In all cases the linear regression model is statistically significant, based on the rejection of the null hypothesis that $\mathrm{r}=0$ when conducting a $t$-test at a $95 \%$ confidence level.

\section{Prediction of bed evolution range}

The linear regression of observed BER and $\tau_{95}$ yields a relation in the form of $\mathrm{BER}_{\text {pred. }}=m \cdot \tau_{95}+b$, where $\mathrm{BER}_{\text {pred. }}$ is the predicted BER based on bed shear stress $\left(\tau_{95}\right)$. The slope $m$ and intercept $b$ depend on the model setup (T, TW, TWS). The predicted BERs for the different scenarios are shown together with observations in Fig. 9. In the purely tidally driven scenario (T, Fig. 9b) the spatial structure of BER already resembles the observations (Fig. 9a). The BER is higher in tidal channels and tidal inlets, although the overall amplitude and the spatial extent of high BER ( $>4 \mathrm{~m}$ ) is underestimated. The difference between scenarios $T$ and $T W$ is hardly discernible (Fig. 9b, c). Therefore, the effect of winddriven currents on the BER seems to be of less importance. In contrast, the full forcing setup (TWS, Fig. 9d) yields increased levels of BER, especially in shallower areas. However, high values of BER ( $>4 \mathrm{~m}$ ) are still underestimated.

In order to analyse the contributions of individual forcing terms (tides, wind, waves), their individual predictive power is further investigated. The difference of BER pred. $_{\text {and }}$ BER for each forcing scenario is normalised with the observed BER, resulting in the following normalised error measure: 


$$
\mathrm{BER}_{\text {error }}=\frac{\text { BER }_{\text {pred. }}-\text { BER }}{\text { BER }}
$$

BER $_{\text {error }}$ is subsequently utilised to assess the main driving forces. Theoretically, BERerror should be zero for full predictive performance of the forcing mechanism under consideration. Due to the variability of the data and the uncertainty of the model, a sensitivity analysis on a finite cut-off value of $\mathrm{BER}_{\text {error }}$ resulted in a criterion of $\left|\mathrm{BER}_{\text {error }}\right|<0.2$.

For a differentiation of the contributions of wind and waves, the difference between individual $\tau_{95}$ results is taken. The wind effect $(W)$ can be assessed from $W=T W-T$, and the effect of waves $(S)$ from $S=T W S-T W$. The area of high predictive power for waves, tides, and the combined effect of tides, wind and waves is shown in Fig. 10. The calculation was limited to the area where the observed BER exceeds $0.5 \mathrm{~m}$ (grey colours in Fig. 10). The effect due to wind alone is negligible and is not shown here. Note that the individual

\section{Kösters, Winter: Exploring German Bight coastal morphodynamics based on modelled bed shear stress. Geo-Mar Lett 34 (2014), S. 21-36.}

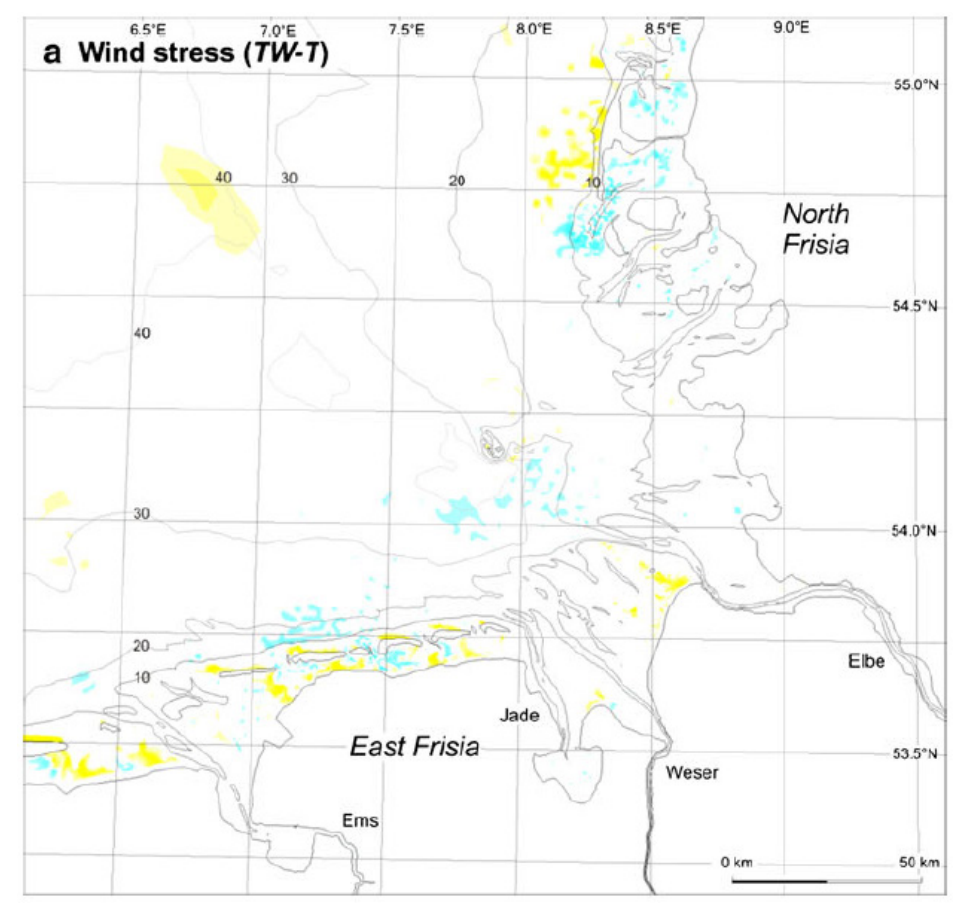




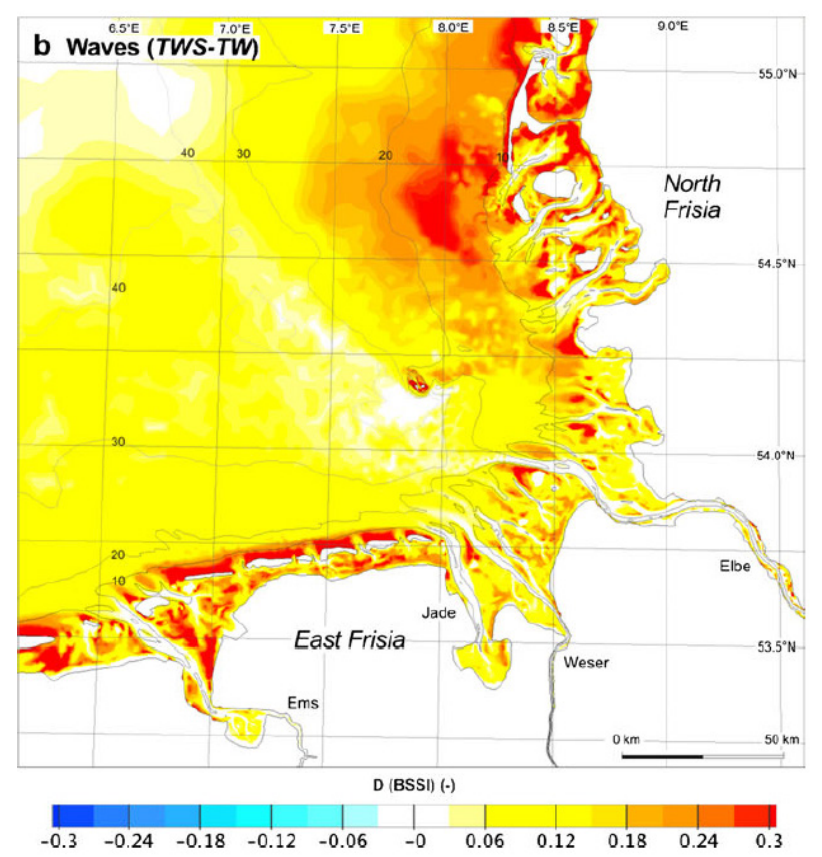

Kösters, Winter: Exploring German Bight coastal morphodynamics based on modelled bed shear stress.

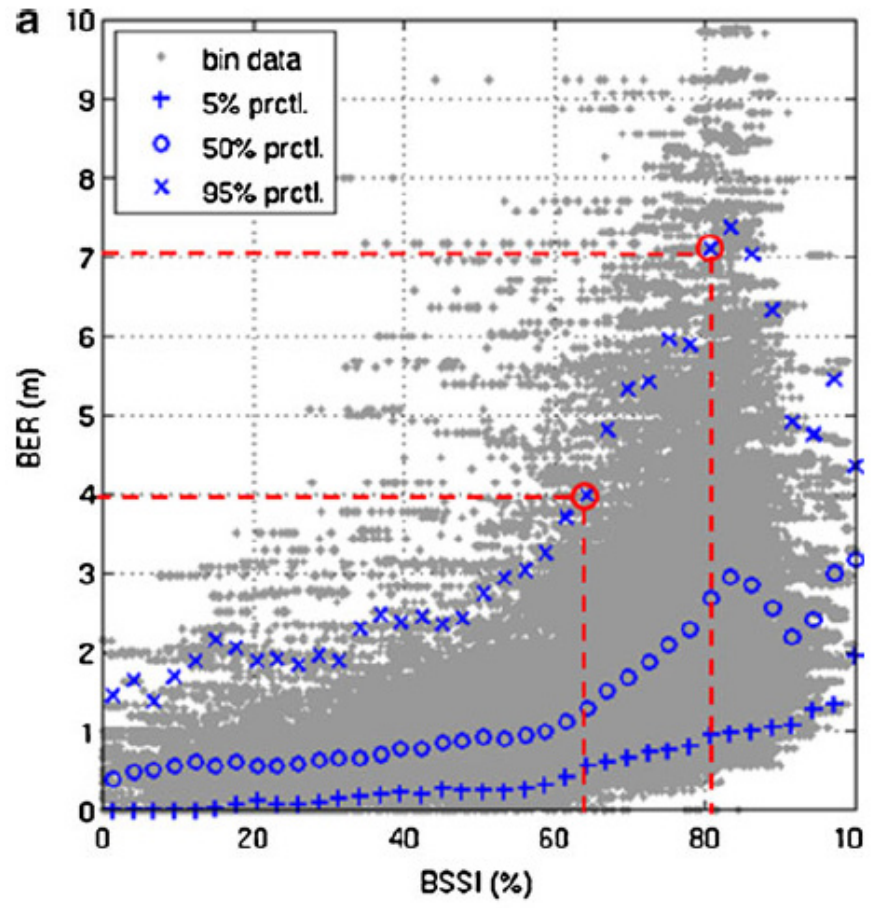




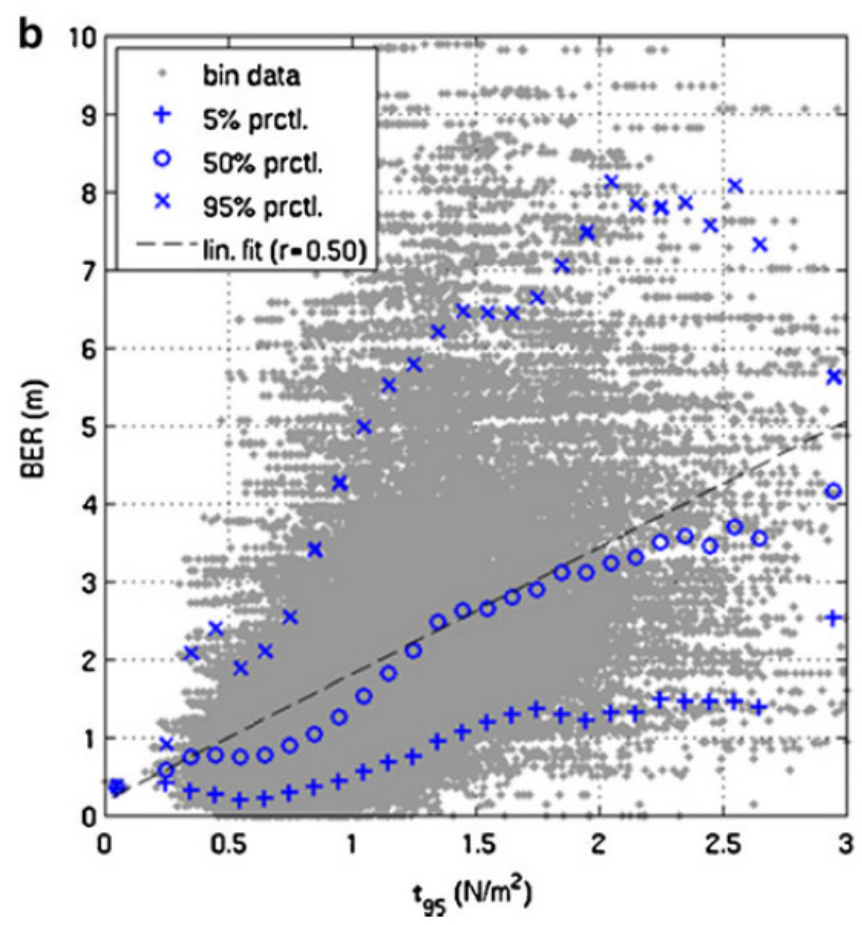

Fig. 8 Correlation of $\mathbf{a}$ BSSI and BER, and $\mathbf{b} \tau 95$ and BER

layers representing the forcing factors are stacked. Thus, there are areas which may be explained by different forcing factors, e.g. by tides or by waves. Areas where tidal forcing alone is sufficient to explain the observed BER are shown as a top layer. This is primarily the case in tidal channels and tidal inlets (blue colours in Fig. 10). The effects of waves alone explain most of the observed BER in the foreshore regions of the East Frisian and North Frisian islands (red colours in Fig. 10). A larger portion of the observed BER, especially in the areas occupied by tidal flats, can be explained only when taking into account the combined effect of tides, wind and waves (green colours in Fig. 10). Interestingly, the combined effect of tides, wind and waves cannot explain all the regions which would be explained by tides only. This indicates that either wind or wave effects might be overestimated in the model.

\section{Discussion}

\section{Analysis of bed shear stress}

The bed shear stress applied in the present paper has been demonstrated to be a useful indicator of other coastal properties in earlier work, e.g. suspended particulate matter in the German Bight (Stanev et al.2009). In order to obtain significant spatial correlations representative measures are needed - in the present case, the 95 th percentile of bed shear stress $\left(\tau_{95}\right)$ and bed shear stress intensity (BSSI) were chosen. It should be noted that, although bed shear stress is a standard parameter calculated in any hydrodynamic modelling system, differences are to be expected due to the 
implementation of flow and wave forcing (see review in Le Hir et al. 2007). Absolute numbers given here are thus of indicative nature. As expected, the model results show the highest shear stress in tidal channels and tidal inlets due to tides. The relatively small wind effect is not surprising, considering that wind-induced velocities at the bed are low compared to the tidally driven component. The significance of wave action in terms of maximal bed shear stress in the foreshore region can clearly be seen (Fig. 5b), which is in line with previous studies (van der Molen 2002).

It should be noted that in this study wave-induced radiation stresses are not taken into account and, therefore, waveinduced currents are ignored. This may underestimate the influence of waves in foreshore regions. Moreover, the model does not account for the effect of large bed forms such as dunes, which certainly have an effect on the flow field (Lefebvre et al. 2011, 2013). Small-scale bed forms such as ripples are taken into account with a uniform roughness length. At an even smaller scale, the effects of grain roughness are taken into account based on the observed sediment distribution.

\section{Correlation of bed evolution range and bed shear stress}

The numerical modelling of the large-scale and long-term morphodynamic evolution of estuarine systems requires a coupled 3D hydrodynamic and sediment transport simulation which, while being computationally feasible today, is hardly successful in reproducing decadal morphodynamic evolution (Lesser et al. 2004; Winter 2006; Chu et al. 2013). Thus, here

Kösters, Winter: Exploring German Bight coastal morphodynamics based on modelled bed shear stress.
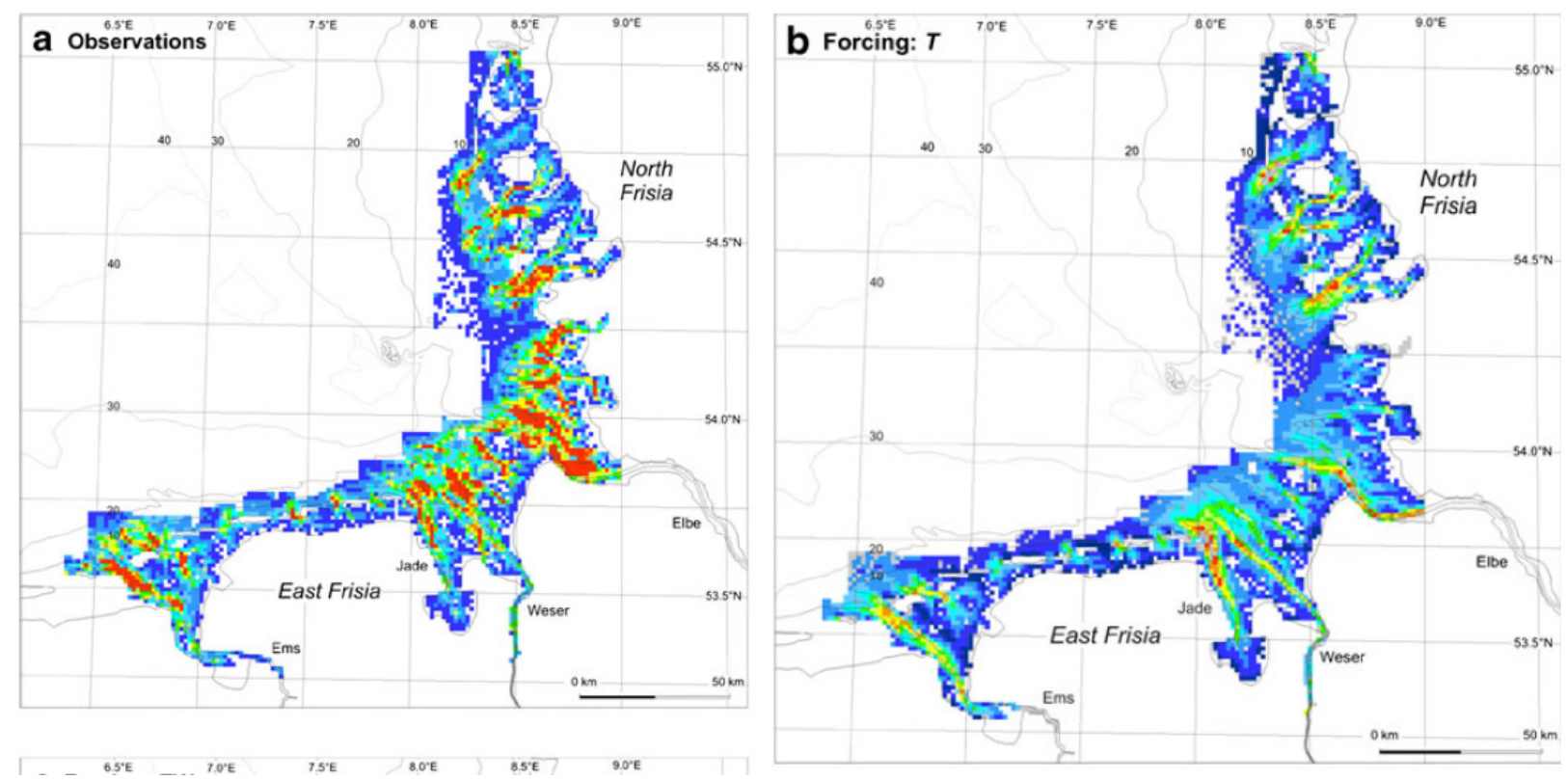


\section{Autorenfassung}

Kösters, Winter: Exploring German Bight coastal morphodynamics based on modelled bed shear stress, 2014

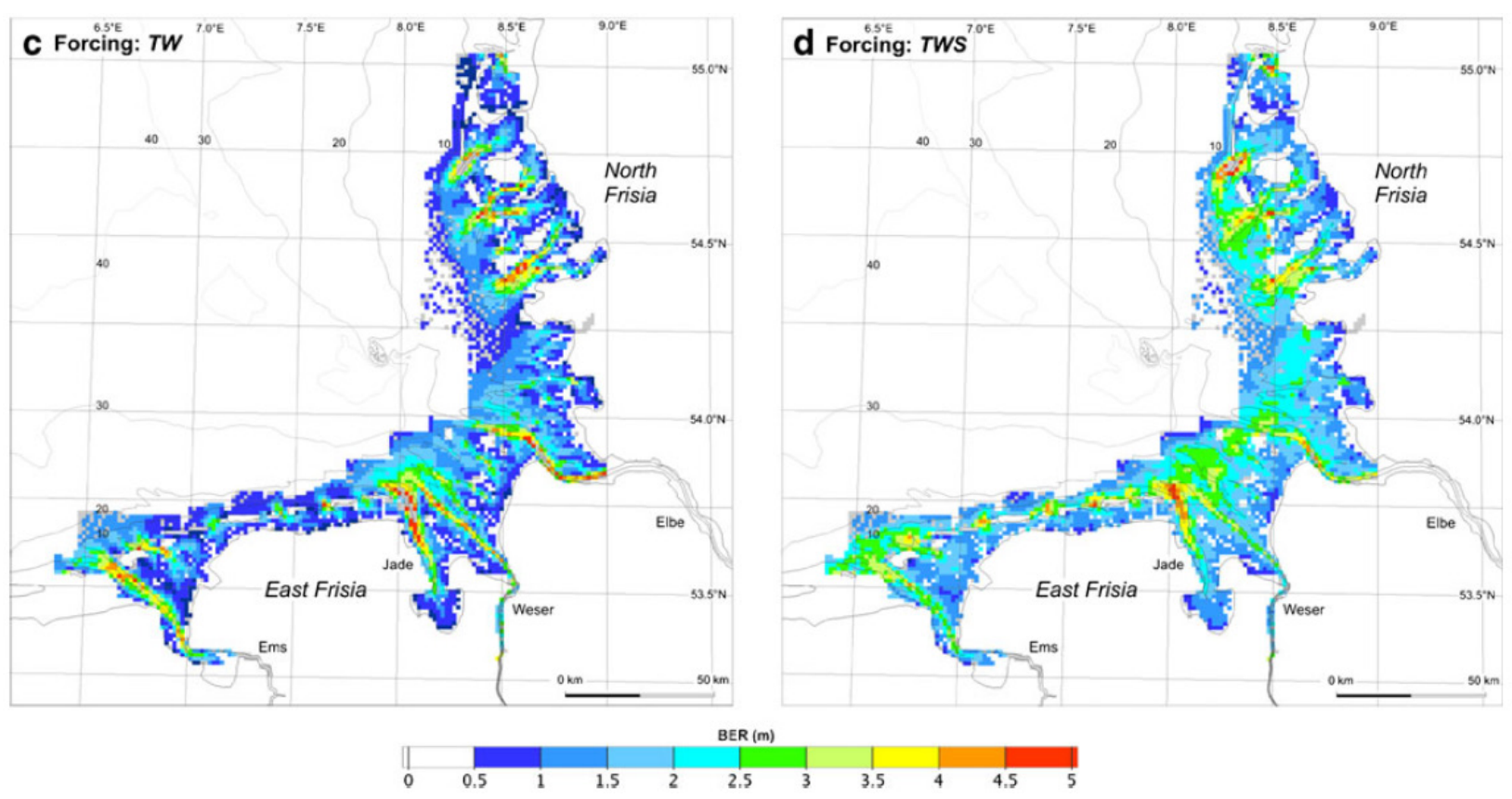

Fig. 9 Bed elevation range based on a observations, $\mathbf{b}$ tides only, $\mathbf{c}$ tides and wind stress, and d tides, wind stress and waves

the bed shear stress, which is one of the prime input parameters of sediment transport models, has been tested whether it correlates with the observed bed evolution range as an integral measure of morphological activity. A scattered but significant correlation was found for the 95th percentile of bed shear stress $\left(\tau_{95}\right)$ as a measure of maximum force exerted on the bed and local BER. This correlation has not been reported before and may be applied to other coastal settings.

The correlation between local BER and bed shear stress can be reduced if the local context of the BER does not resemble the local context of bed shear stress. For instance, the outer Elbe estuary experiences a pronounced migration of a tidal channel which results in a large area of high BER, as it integrates the morphodynamic activity of two decades. Corresponding bed shear stresses, on the other hand, are only reproduced in the tidal channels (or at the banks). This problem was partly overcome by the present approach to simulate the hydrodynamic flow on separate grids for each year, allowing for changes in bathymetry. However, the application of annual topographies cannot account for intra-annual 
Kösters, Winter: Exploring German Bight coastal morphodynamics based on modelled bed shear stress. Geo-Mar Lett 34 (2014), S. 21-36.

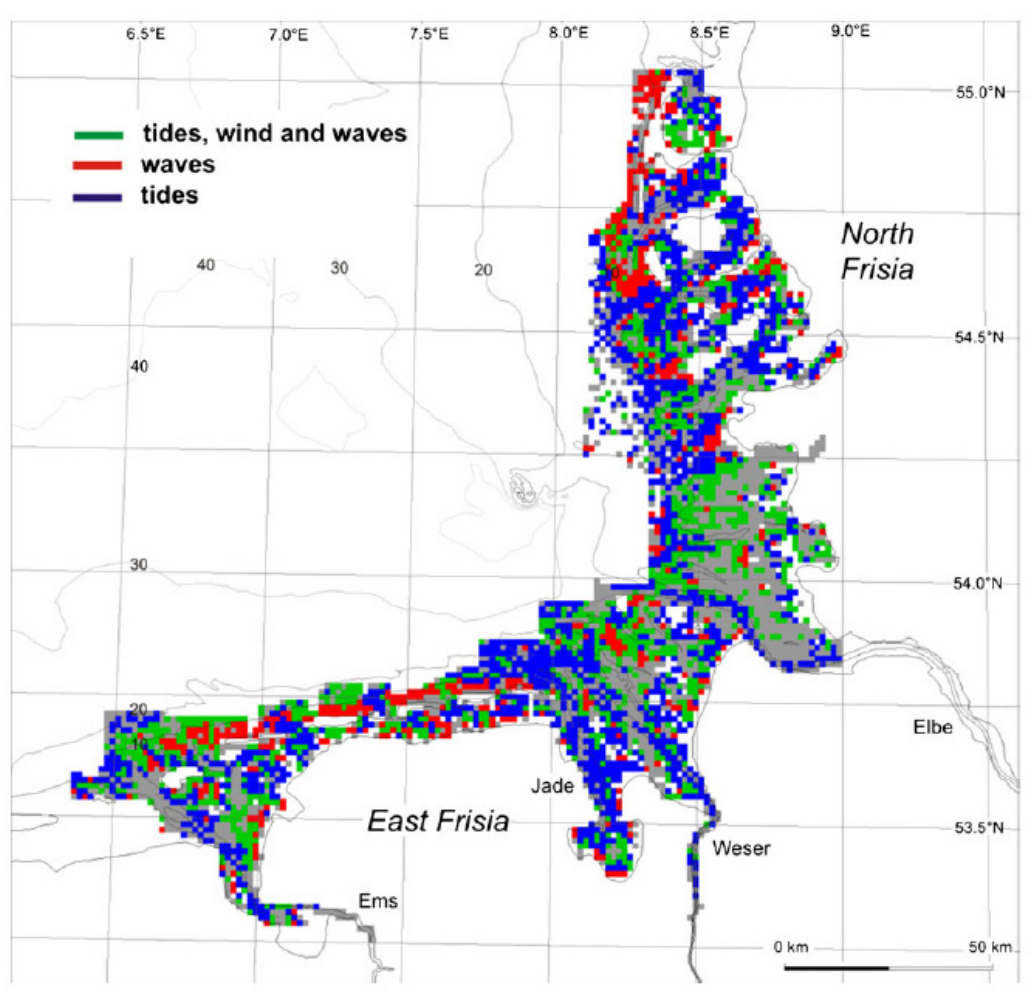

Fig.10 Dominant processes as inferred from model predictive performance for tides, waves, and the combined action of tides, wind and waves

changes in topography. Hence, it was necessary to interpolate measured BER and calculated bed shear stress on a uniform but coarser grid.

The correlation of observations and model results is hindered by the aim to take into account long time spans for observations (1984-2006) on the one hand but computational restrictions for the model on the other hand (1996-2007). The 12 years of variability in the forcing data of the model cover a broad range of meteorological and tidal conditions (e.g. storm events, spring-neap tides, river discharge) and can be seen as representative for the time span covered by observations. Another obvious reason for the observed scatter in the relation of BER and $\tau_{95}$ is anthropogenic impact, e.g. dredging in tidal channels, which has not been taken into account; thus, it is possible that the BER is overestimated compared to the natural equilibrium in navigational waterways. It should be mentioned that the influence of biota on bed shear stress is not accounted for in the model but will affect the measured BER. Salt marsh vegetation, as an example, will considerably alter bed 
shear stress and consequently erosion (e.g. Le Hir et al. 2007). This is an important subject of ongoing research and a key complement to related studies dealing with the various impacts of sea-level rise and climate forcing on salt marsh dynamics in both the German and other sectors of theWadden Sea (e.g. Kolditz et al. 2012; Kim et al. 2013).

\section{Prediction of bed evolution range}

The predictive power of the regression analysis depends on the explained variance of the regression. Although the median of the BER can be explained well, the deviation of the median value for the 5 th and 95th percentiles is in the order of $100 \%$ (Fig. 8). Due to this deviation it has to be expected that the prediction of BER based on $\tau_{95}$ cannot reproduce the characteristic high values within the tidal channels very well.

Kösters, Winter: Exploring German Bight coastal morphodynamics based on modelled bed shear stress. Geo-Mar Lett 34 (2014), S. 21-36.

However, in these areas human impact (e.g. dredging) results in a bias of the calculated BER towards an overestimation.

The prediction of BER based on $\tau_{95}$ illustrates that the numerical simulation of morphologically active regions in principle should be possible (Fig. 9). Even if the magnitude of the predicted BER between observations and model diverges strongly at the local level, the overall structure is undoubtedly similar. While these results are encouraging, it should be pointed out that the modelling does not contain any sediment dynamics at this stage. The changes of morphology in nature are due to divergences of sediment transport. In turn, sediment transport depends crucially on the sediment properties (grain size, porosity, critical shear stress for erosion). In a purely hydrodynamic model these properties are not taken into account. The relatively small effect of the wind-induced circulation observed here may be different when sediment transport is explicitly taken into account. In the German Bight the most frequent wind directions are westerly, which results in a residual cyclonic circulation strongly affecting sediment transport.

\section{Conclusions}

In this study the diverse morphological activity of the German Bight as shown in the bed elevation range for two decades has been related to hydrodynamic forcing. Two descriptive measures are proposed: the bed shear stress intensity (BSSI) and 95 th percentile of bed shear stress $\left(\tau_{95}\right)$ as derived from longterm model simulations. Certain values of the BSSI have been shown to reflect a threshold for likely values of the BER, e.g. half of the areas with a BER exceeding $1 \mathrm{~m}$ can be identified by a BSSI larger than $60 \%$. This approach may be further developed for questions related to an 
assessment of bed stability (e.g. landward power cable connections). More importantly, the $\tau_{95}$ was shown to significantly explain local variations of the BER. In terms of morphodynamic modelling, this encouraging result was obtained using a first-order simplistic manner of data assimilation, i.e. the application of individual annual topographies in the model, possibly a way forward in morphodynamic modelling itself (cf. Chu et al. 2013).

A systematic parameter study has shown the relative effect of tidal currents, wind-driven currents and waves on morphological changes. Results mainly corroborate previous findings based on observations only (Winter 2011). Tidal currents are the main driver of the very high morphological activity observed in the tidal channels of the Ems, Weser and Elbe estuaries, the Jade Bay and the tidal inlets between the islands. This also holds for the backbarrier tidal flats of the North Frisian Wadden Sea. The morphodynamics of the foreshore areas of the barrier island systems are mainly wave-driven, but in the deeper areas $(>10 \mathrm{~m})$ also tides and wind-driven currents have an effect. The active open tidal flats (outer Ems, NeuwerkerWatt, Dithmarschen Bight) are mainly affected by the combination of tides, winds and waves. The East Frisian Wadden Sea shows high local variability and cannot be sufficiently explained by the rather coarse characterisation.

This case study dealing with a highly diverse geomorphological setting can serve as guide for investigations of other, similar environments. The study has a regional focus in that extensive German Bight measurement data and an existent validated model were used; however, this methodology for detailed evaluations of the morphodynamic characteristics of coastlines is applicable to any other domain. In the present case, model performance should be measurablyimproved by integrating the roles of other key drivers such as sediment dynamics and salt marsh stabilisation.

\section{Acknowledgements}

This research was funded by the Federal Ministry of Education and Research as part of the "Modelbased analysis of longterm morphodynamic processes in the German Bight (AufMod)" project (03KIS083 and 03KIS084). This research was co-funded through the DFG-Research Center/Excellence Cluster "The Ocean in the Earth System". Model input data were provided by the Federal Maritime and Hydrographic Agency (BSH), the German National Meteorological Service (DWD), and the Federal Waterways and Shipping Administration (WSV). We would like to thank Wencke Appel for her technical support in preparing the figures. We highly appreciate the constructive comments of three anonymous reviewersand the editors Burg W. Flemming and Monique T. Delafontaine.

\section{References}

BrommerMB, Bochev-van der Burgh LM (2009) Sustainable coastal zone management: A concept for forecasting long-term and large-scale coastal evolution. J Coastal Res 251:181-188. doi:10.2112/07-0909.1 
Casulli V, Zanolli P (2005) High resolution methods for multidimensional advection-diffusion problems in free-surface hydrodynamics. Ocean Modell 10(1/2):137-151. doi:10.1016/ j.ocemod.2004.06.007

Chu K, Winter C, Hebbeln D, Schulz M (2013) Improvement of morphodynamic modeling of tidal channel migration by nudging. Coastal Eng 77:1-13. doi:10.1016/j.coastaleng.2013.02.004

Cowell PJ, Thom BG (1994) Morphodynamics of coastal evolution. In: Carter RWG, Woodroffe CD (eds) Coastal evolution. Late quaternary shoreline morphodynamics. Cambridge University Press, Cambridge, pp 33-86

Dam G, Bliek AJ, Labeur RJ, Ides S, Plancke Y (2008) Long term process based morphological model of the Western Scheldt estuary. In: Dohmen-Janssen CM, Hulscher SJMH (eds) River, coastal, and estuarine morphodynamics. RCEM 2007: Proc 5th IAHR Symp River, Coastal, and Estuarine Morphodynamics, Enschede, The Netherlands, pp 1077-1084, 17-21 September 2007. Taylor \& Francis, London

Doms G, Steppeler J, Adrian G (2002) Das Lokal-Modell LM. Promet 27(3/4):123-128

Edmonds DA, Slingerland RL (2007) Mechanics of river mouth bar formation: implications for the morphodynamics of delta distributary networks. J Geophys Res 112(F2). doi:10.1029/2006JF000574

Ehlers J (1988) The morphodynamics of the Wadden Sea. Balkema, Rotterdam

Flemming BW, Davis RAJ (1994) Holocene evolution, morphodynamics and sedimentology of the Spiekeroog barrier island system (southern North Sea). Senckenberg marit 24(1):117-155

Kösters, Winter: Exploring German Bight coastal morphodynamics based on modelled bed shear stress. Geo-Mar Lett 34 (2014), S. 21-36.

Flemming BW, Hansom JD (2011) Estuarine and coastal geology and geomorphology - A synthesis. In: FlemmingBW, Hansom JD (eds) Estuarine and coastal geology and geomorphology, vol 3, Treatise on estuarine and coastal science. Elsevier, Amsterdam, pp 1-5

Flöser G, Burchard H, Riethmüller R (2011) Observational evidence for estuarine circulation in the German Wadden Sea. Cont Shelf Res 31(16):1633-1639. doi:10.1016/j.csr.2011.03.014 
Ganju NK, Jaffe BE, Schoellhamer DH (2011) Discontinuous hindcastsimulations of estuarine bathymetric change: A case study from Suisun Bay, California. Estuar Coast Shelf Sci 93(2):142150. doi: 10.1016/j.ecss.2011.04.004

Gayer G, Dick S, Pleskachevsky A, Rosenthal W (2006) Numerical modeling of suspended matter transport in the North Sea. Ocean Dyn 56(1):62-77. doi:10.1007/s10236-006-0070-5

Gerritsen H, Boon J, van der Kaaij T, Vos R (2001) Integrated modelling of suspended matter in the North Sea. Estuar Coast Shelf Sci 53(4): 581-594. doi:10.1006/ecss.2000.0633

Grant WD, Madsen OS (1979) Combined wave and current interaction with a rough bottom. J Geophys Res 84(C4):1797. doi:10.1029/ JC084iC04p01797

Junge I, Wilkens J, Hoyme H, Mayerle R (2006) Modelling of mediumscale morphodynamics in a tidal flat area in the south-eastern German Bight. Die Küste 69:279-311

Kim D, Grant WE, Cairns DM, Bartholdy J (2013) Effects of the North Atlantic oscillation and wind waves on salt marsh dynamics in the DanishWadden Sea: a quantitative model as proof of concept. Geo- Mar Lett 33(4):253-261. doi:10.1007/s00367-013-0324-4

Kolditz K, Dellwig O, Barkowski J, Badewien TH, Freund H, Brumsack H-J (2012) Geochemistry of salt marsh sediments deposited during simulated sea-level rise and consequences for recent and Holocene coastal development of NW Germany. Geo-Mar Lett 32(1):49-60. doi:10.1007/s00367-011-0250-2

Le Hir P, Monbet Y, Orvain F (2007) Sediment erodability in sediment transport modelling: can we account for biota effects? Cont Shelf Res 27(8):1116-1142. doi:10.1016/j.csr.2005.11.016 Lefebvre A, Ernstsen VB, Winter C (2011) Influence of compound bedforms on hydraulic roughness in a tidal environment. Ocean Dyn 61(12):2201-2210. doi:10.1007/s10236-0110476-6

Lefebvre A, ErnstsenVB,Winter C (2013) Estimation of roughness lengths and flow separation over compound bedforms in a natural-tidal inlet. Cont Shelf Res 61(62):98-111. doi:10.1016/j.csr.2013.04.030

Lesser G, Roelvink J, van Kester J, Stelling G (2004) Development and validation of a threedimensionalmorphologicalmodel. Coastal Eng 51(8/9):883-915. doi:10.1016/j.coastaleng. 2004.07.014

Loewe P, Klein H, Weigelt-Krenz S (eds) (2013) System Nordsee - 2006 \& 2007: Zustand und Entwicklungen. Berichte des BSH, vol 49,Hamburg 


\section{Autorenfassung}

Kösters, Winter: Exploring German Bight coastal morphodynamics based on modelled bed shear stress, 2014

Lyard F, Lefevre F, Letellier T, Francis O (2006) Modelling the global ocean tides: Modern insights from FES2004. Ocean Dyn 56(5/6): 394-415. doi:10.1007/s10236-006-0086-x

Malcherek A (2010) Gezeiten und Wellen. Die Hydromechanik der Küstengewässer, 1st edn. Vieweg+Teubner, Wiesbaden

Masselink G, Hughes MG, Knight J (2011) Introduction to coastal processes and geomorphology, 2nd edn. Hodder Education, London

Niedermeier A, Hoja D, Lehner S (2005) Topography andmorphodynamics in the German Bight using SAR and optical remote sensing data. Ocean Dyn 55(2):100-109. doi:10.1007/s10236-005-0114-2

Otto L, Zimmerman J, Furnes G, Mork M, Saetre R, Becker G (1990) Review of the physical oceanography of the North Sea. Neth J Sea Res 26(2/4):161-238. doi:10.1016/00777579(90)90091-T

PulsW, Heinrich H, Mayer B (1997) Suspended particulatematter budget for the German Bight.Mar Pollut Bull 34(6):398-409. doi:10.1016/ S0025-326X(96)00161-0

Roelvink D, Reniers A (2012) A guide to modeling coastal morphology. Advances in coastal and ocean engineering, vol 12. World Scientific, Hackensack

Schneggenburger C, Günther H, Rosenthal W (2000) Spectral wave modelling with non-linear dissipation: validation and applications in a coastal tidal environment. Coastal Eng 41(1/3):201235. doi:10. 1016/S0378-3839(00)00033-8

Schwarzer K, Ricklefs K, Bartholomä A, Zeiler M (2008) Geological development of the North Sea and the Baltic Sea. Die Küste 74:1-17

Son CS, Flemming BW, Bartholomä A (2011) Evidence for sediment recirculation on an ebb-tidal delta of the East Frisian barrier-island system, southern North Sea. Geo-Mar Lett 31(2):87100. doi:10. 1007/s00367-010-0217-8

Soulsby R (1997) Dynamics of marine sands. A manual for practical applications, Telford Stanev E, Dobrynin M, Pleskachevsky A, Grayek S, Günther H (2009) Bed shear stress in the southern North Sea as an important driver for suspended sediment dynamics. Ocean Dyn 59(2):183194. doi:10.1007/s10236-008-0171-4

Staneva J, Stanev EV, Wolff J, Badewien TH, Reuter R, Flemming B, Bartholomä A, Bolding K (2009) Hydrodynamics and sediment dynamics in the German Bight. A focus on observations and 
numerical modelling in the East Frisian Wadden Sea. Cont Shelf Res 29(1):302-319. doi:10.1016/j.csr.2008.01.006

Sündermann J, Pohlmann T (2011) A brief analysis of North Sea physics. Oceanologia 53(3):663689. doi:10.5697/oc.53-3.663

Syvitski JPM, Slingerland RL, Burgess P,Meiburg E,MurrayAB,Wiberg P, Tucker G, Voinov AA (2010) Morphodynamic models: An overview. In: Vionnet CA (ed) River, coastal, and estuarine morphodynamics. RCEM 2009. Taylor \& Francis, Boca Raton, pp 3-20

van der Molen J (2002) The influence of tides, wind and waves on the net sand transport in the North Sea. Cont Shelf Res 22(18/19):2739- 2762. doi:10.1016/S0278-4343(02)00124-3

van der Wegen M, Dastgheib A, Jaffe BE, Roelvink D (2011) Bed composition generation for morphodynamic modeling: Case study of San Pablo Bay in California, USA. Ocean Dyn 61(2/3):173-186. doi:10.1007/s10236-010-0314-2

van Dijk TA, Kleuskens M, Dorst LL, van der Tak C, Doornenbal PJ, van der Spek A,Hoogendoorn RM, Rodriguez Aguilera D, Menninga PJ, Noorlandt RP (2012) Quantified and applied sea-bed dynamics of the Netherlands continental shelf and the Wadden Sea. In: Kranenburg WM, Horstman EM,Wijnberg KM (eds) NCK-days 2012: Crossing Borders in Coastal Research. University of Twente, Enschede

van Rijn LC (1993) Principles of sediment transport in rivers, estuaries, and coastal seas. Aqua Publications, Amsterdam

Vested HJ, Tessier C, Christensen BB, Goubert E (2013) Numerical modelling of morphodynamicsVilaine Estuary. Ocean Dyn 63(4):423-446. doi:10.1007/s10236-013-0603-7

Vink A, Steffen H, Reinhardt L, Kaufmann G (2007) Holocene relative sea-level change, isostatic subsidence and the radial viscosity structure of the mantle of northwest Europe (Belgium, the Netherlands, Germany, southern North Sea). Quat Sci Rev 26(25/28):3249-3275. doi:10.1016/j.quascirev.2007.07.014

Weisse R, Günther H (2007)Wave climate and long-term changes for the Southern North Sea obtained from a high-resolution hindcast 1958- 2002. Ocean Dyn 57(3):161-172. doi:10.1007/s10236-006-0094-x

Winter C (2006) Meso-scale morphodynamics of the Eider Estuary: Analysis and numerical modelling. J Coastal Res 39:498-503 Winter C (2011)Macro scale morphodynamics of the German North Sea coast. J Coastal Res 64:706-710 Winter C, Bartholomä A (2006) “Coastal dynam- 
ics and human impact: south-eastern North Sea", an overview. Geo-Mar Lett 26(3):121124. doi:10.1007/s00367-006-0024-4

Zeiler M, Schulz-Ohlberg J, Figge K (2000) Mobile sand deposits and shoreface sediment dynamics in the inner German Bight (North Sea). Mar Geol 170(3/4):363-380. doi:10.1016/S00253227(00)00089-X

Zeiler M, Schwarzer K, Ricklefs K (2008) Seabed morphology and sediment dynamics. Die Küste 74:31-44 